\title{
Editorial
}

\section{Governance in the age of unknown unknowns}

\author{
International Journal of Disclosure and Governance (2009) 6, 85-88. doi:10.1057/jdg.2009.2
}

'Reports, that say that something hasn't happened are always interesting to me, because as we know, there are known knowns; there are things we know we know. We also know there are known unknowns; that is to say we know there are some things we do not know. But there are also unknown unknowns - the ones we don't know we don't know. And if one looks throughout the history of our country and other free countries, it is the latter category that tend to be the difficult ones. And so people who have the omniscience that they can say with high certainty that something has not happened or is not being tried have capabilities that are [beyond mineit'. (Donald Rumsfeld, former US Secretary of Defense)

This famous quotation from former US Defense Secretary Donald Rumsfeld crossed my mind as I was listening to the latest discussion on the proposed US recovery plan now moving through Congress. After the certainties of a few months back that the 'Paulson Plan' or the 'Gordon Brown Plan' would get the financial system back on track, the view today seems to be that no one knows what is going to happen and what solutions will actually work. Instead, there is an endless stream of gloomy statistics, dire to an extent not seen since the Great Depression, and even that familiar example is now hedged with reminders that it took a decade and a World War for recovery to begin.

It is becoming clear that this is no mere blip of confidence by investors and consumers, but a total crisis of beliefs about what people took for granted about the economy and the rules by which it operates. As an African banker told Thomas Friedman of the New York Times at the recently concluded Davos Summit, 'We're all going to have to learn to live with a lower level of trust in our lives'. At least this quote has within it the promise of life going forward. Perhaps one that better captures the spirit of the times is that by a senior Wall Street securities lawyer who began his talk at a governance conference I recently attended with the words, 'I don't think that any of us have any idea how close we have come to the end of capitalism as we know it'.

As if we didn't have enough to worry about with the collapse of such household names as Lehmann Brothers, General Motors, Woolworths in the United Kingdom and Circuit City in the United States, confidence and trust were further hammered by the US $\$ 50$ billion Madoff Ponzi scheme and numerous other frauds that bad market conditions forced to the surface. And lest we think that the troubles are confined to the Western economies, there comes the astonishing scandal at Satyam in India, whose founder and CEO B. Ramalinga Raju confessed to doing what was previously thought impossible: to commit a long-standing fraud of a firm's cash accounts.

In the light of all this, Secretary Rumsfeld's warning has resonance: what we really have to worry about are not just the disasters that are unfolding whose true costs are uncertain, but the potential for failures yet to come in 
areas that no one is paying attention to at the moment. After all, just a year ago the concept of a credit squeeze brought about by a fall in US housing prices would also have fallen into the category of an unknown unknown.

Today's known unknown is what it will take to get the economy moving again. At least we have now come to the stage of acknowledging that there isn't a magic bullet to end the crisis: not interest rate cuts, not a stimulus package, tax cuts, new regulation or currency depreciations. All these steps have been tried and now we are at the stage of simply hoping that if any one of them will not necessarily work, then by doing all of them some combination will do the trick.

But if and when we do so, what the readers and writers of this journal have to focus on are how the mechanisms of corporate governance have to change to deal with a world not just of risk and uncertainty, but of Rumsfeld's unknown unknowns, for as he says, the lessons of history indicate that these are really what pose the most difficult challenges.

For example, there is much focus today on the concept of 'fat tails', the idea that the risk of outlier events with outsize effects on the very survivability of a firm is more common than had been assumed in such standard risk management tools, as Value at Risk (VAR). The same point is made more colloquially with the complaint that 'how come 10000 year events seem to be taking place every few years now?' from the fall in housing prices, to the 1998 Long Term Capital Management crisis or the 1987 Black Monday fall of stock prices on Wall Street? There is an urgent debate now on whether the likelihood of such catastrophes is rising in an interconnected, globalised world, or whether such techniques as VAR are perfectly capable of taking such possibilities into account by simply adjusting the presumed risk profile: in other words, whether one is dealing with known or unknown unknowns.

The problem is that many of the tools of governance are not just unable to cope with unknown unknowns, they actively ignore them.
Hence, as with VAR, many statistical techniques, such as the sampling methods used by auditors, drop 'outlier' observations - in other words, those from the tails of a distribution - as being anomalous and therefore not useful for predictive purposes. And that argument is certainly true if what is being predicted is the predictable, the known unknowns, but it is an utterly counterproductive procedure if the unknown unknown is what is being sought. I hasten to add that academics are equally guilty of such tactics, 'winsorising' data in their empirical studies to eliminate outliers on the assumption that because such data does not fit their theories then they must be statistical flukes that have no information content. When one considers the definition of this methodology one can also see a reflection of the stated rationale for many governance practices, from the ratcheting up of executive compensation to the often dismissive response of boards of directors and regulators to whistleblowers: 'The practice of modifying outliers in the data by making them no more extreme than the most extreme data that you believe to be relevant or accurately measured'.

This preference for the known over the unknown unknown is justifiable if the latter is not just less likely than the former, but if its consequences are correspondingly insignificant. But as with a 10000-year flood or hurricane, some fat tail events, while rare, often have outsize consequences. Thus their expected costs - the product of likelihood and outcome - may well be more materially significant than they are given credit for. Not for nothing did Nassim Taleb of 'Black Swan' fame describe the strategy of banks trading derivatives as 'picking pennies in front of a steam roller'.

Now it might be argued that it is asking too much for anyone to plan for something that cannot be anticipated, but in response, it needs to be kept in mind that what is an unknown unknown for one person may be the expectation of another. Hence, recall that while the US government concluded that it was unprepared for the 9-11 terrorist attacks because of 'a lack of imagination' that such a thing was even 
possible, the use of hijacked planes as flying bombs had been plot device in numerous thrillers over the years. In the case of the current crisis, well-deserved fame has now come to Nouriel Roubini of New York University, the already mentioned Nassim Taleb, and several contrarian investors who had long condemned the entire subprime mortgage-fuelled derivative-based banking system as a delusional and greed-driven house of cards.

Players in the governance arena, from boards of directors and regulators to internal and external auditors are now being called upon to pay more attention to risk management, but that essentially means dealing with uncertainty, which is a known unknown. They had better also start thinking about the unthinkable, which is another way of describing the unknown unknowns. For example, too often directors base their beliefs in the CEO on their personal reactions to his or her perceived honesty and integrity. But which director will ever admit that they looked into the eyes of a Ken Lay, a Bernie Ebbers or a Ramalinga Raju and saw a crook? Don't forget that the most sickening aspect of the Madoff scandal is how he stole from those closest to him and presumably knew him best: his oldest friends and their extended family, religious and educational associates and the like.

Perhaps precisely in circumstances where the known unknown seems minimal, thanks, for example, to the regard with which the CEO is universally held (recall that Ramalinga Raju of Satyam fame was a revered philanthropist - and the recipient just months before he admitted his fraud, of a major good governance award) is when someone, be it an auditor, regulator or director, has to play the Devil's advocate and ask what would happen if everything was really the opposite of what it seemed. After all, when uncertainty is great, risk management and internal controls are likely to be the strongest, which provides some robustness for dealing with unexpected unknown unknowns. But when everything seems fine, be it the years of steady returns from Madoff funds, growth at Satyam or the outsize profits at investment banks, that is when complacency sets in and the potential for damage the greatest. Or to put it another way, as recent history shows, a major earthquake in a area known for them, such as Los Angeles, causes minimal deaths while when a similar size one takes place somewhere where quakes are rare, such as Armenia, thousands die.

Another danger is that even when the unknown unknown has actually occurred, it is hard for people to let go of past assumptions and develop new and more appropriate governance practices. Auditors have yet to demonstrate that they even understand the concept of fat tails, much less adapt audit practices to take them into account. A disappointing aspect of the Obama administration's response to the credit crisis is that they haven't come out in favour of significant governance reforms, such as allowing more power to shareholders to discipline boards and managers, even though the arguments made against such reforms in the boom years now seem absurd. And as the SEC's utter failure to take seriously the warnings explicitly and repeatedly made over a 9-year period about Madoff indicate, they lack even the auditor's required standard of 'professional scepticism' let alone wishing to think the unthinkable, that a $\$ 50$ billion fund was nothing more than the largest Ponzi scheme of all time.

But perhaps the finest example of how far mindsets lag realities was a story related to me by a senior hedge fund manager in New York. His firm had an oversight meeting late last year with the New York Federal Reserve at which he disclosed that his fund had been forced to write off up to 2 per cent of its assets because they had been deposited at Lehmann Brothers (note, deposited, not invested). That one could possibly lose even one cent placed in the care of a blue chip firm like Lehmann is truly the realisation of an unknown unknown, but what was the shocked reaction of the Fed? They demanded to know why the risk of losing those deposits hadn't been hedged through the use of a credit default swap - the very same derivative instruments that 
had brought down Lehmann in the first place! Irony, not just insight and imagination, seems to be lacking at our banking regulators.

Of course, as the African banker indicated, it is not a happy world in which there is less trust, and success and integrity are reasons for suspicion rather than comfort, but after all, the rationale for governance is ensuring the peace of mind of shareholders, not that of those whose responsibility it is to see that the governance is done well. Admittedly, it is hard for people to get their arms around the concept of an unknown unknown. Even Rumsfeld was ridiculed for his statement, which was dismissed as meaningless jargon by critics who failed to understand the importance of the point that he was articulating.

But whether one calls it an unknown unknown, ambiguity, fat tails or black swans, it is essential that those of us in the governance arena start to develop practices that makes us contemplate the unthinkable and prepare to deal with events that are not just the worst case scenario, but worse than what we can even imagine. Only then will we have the assurance that we have done everything possible to cope with everything that is possible.

Michael Alles

Editor 